\title{
OBSTRUCTIVE JAUNDICE AND HAEMOLYTIC DISEASE OF THE NEWBORN
}

BY

\author{
PETER M. DUNN \\ From the Department of Paediatrics, United Birmingham Hospitals
}

(RECEIVED FOR PUbLICATION AUGUST 7, 1962)

Although in most cases of haemolytic disease of the newborn practically all the bilirubin in the serum is of the indirect reacting type, a quarter of a century ago Still (1927) and Hawksley and Lightwood (1934) described cases in which the serum direct reacting bilirubin was raised and signs of obstructive jaundice appeared. This condition came to be known as the 'inspissated bile syndrome' (Hsia, Patterson, Allen, Diamond and Gellis, 1952). In 1959 Oppé and Valaes reported a systematic study of this condition. They confirmed that the findings of hepatosplenomegaly (Lathe, 1955), gross anaemia and hyperbilirubinaemia, including an elevated conjugated fraction (Cornblath, Kramer and Kelly, 1955; Stempfel, Broman, Escardó and Zetterström, 1956), were present at birth. They also noted that the jaundice in these babies took on a greenish hue and that a tendency to bleed sometimes developed.

Recent papers (Billing and Lathe, 1958; Zuelzer and Brown, 1961b) have shown that the 'indirect' fraction is made up of free bilirubin and bilirubin monoglucuronide, both of which are largely formed at extrahepatic sites. The "direct" fraction represents bilirubin diglucuronide which is probably formed only in the liver.

TABLE 1

\begin{tabular}{|c|c|c|c|}
\hline $\begin{array}{l}\text { Aetiolingy of Neonatal } \\
\text { Obstructive Jaundice }\end{array}$ & $\begin{array}{l}\text { No. Seen } \\
\text { in } \\
\text { Present } \\
\text { Series }\end{array}$ & $\begin{array}{l}\text { Neonatal } \\
\text { Deaths }\end{array}$ & $\begin{array}{l}\text { No. } \\
\text { Transferred } \\
\text { to Children's } \\
\text { Hospital }\end{array}$ \\
\hline $\begin{array}{l}\text { Congenital atresia of the bile- } \\
\text { ducts . } \\
\text { Bile-duct compression } \\
\text { Mucoviscidosis } \\
\text { High intest inal obstruction } \\
\text { Haemolytic disease of the new- }\end{array}$ & $\begin{array}{l}2 \\
0 \\
1 \\
0\end{array}$ & $\begin{array}{l}2 \\
0 \\
0 \\
0\end{array}$ & $\begin{array}{l}\mathbf{C} \\
\mathbf{0} \\
1 \\
\mathbf{0}\end{array}$ \\
\hline $\begin{array}{l}\text { born } \\
\text { Idiopathic hepatit is } \cdots \\
\text { Infective hepatitis (viral. } \\
\text { cytomegalic inclusion dis- } \\
\text { ease; bacterial; syphilitic; } \\
\text { cholangitis, toxoplasmosis) }\end{array}$ & $\begin{array}{r}14 \\
1\end{array}$ & $\frac{2}{0}$ & 3 \\
\hline $\begin{array}{l}\text { Toxic' hepatitis (galacto- } \\
\text { saemia; drugs) } \\
\text { Miscellaneous (portal vein } \\
\text { thrombosis, congestive car- }\end{array}$ & 0 & $\mathbf{0}$ & $\mathbf{0}$ \\
\hline diac failure) .. & 0 & $\mathbf{0}$ & $\mathbf{0}$ \\
\hline
\end{tabular}

Infants were designated as showing obstructive jaundice if the direct-reacting serum bilirubin rose above $3 \mathrm{mg}$. $/ 100 \mathrm{ml}$., which is comparable with work by Tisdale, Klatskin and Kinsella (1959) and Zuelzer and Brown (1961b).

\section{Neonatal Obstructive Jaundice}

During 1960 and 1961,18 cases of obstructive jaundice were diagnosed among 6,854 live births at the Maternity and Queen Elizabeth Hospitals. Birmingham.

Inquiries among paediatricians in the City failed to reveal further cases of obstructive jaundice in the neonatal period, following discharge from these maternity units.

In Table 1 these cases are presented under an aetiological classification based on a review of the literature (Hsia et al., 1952; Harris, Andersen and Day, 1954; Nakai and Landing. 1961; Cameron and Hou, 1962).

Thus, haemolytic disease of the newborn was associated with 14 of the 18 cases of obstructive jaundice, two of the four that died, and three of the five that were transferred to a children's hospital. No cases of haemolytic disease without obstructive jaundice required transfer. It should be noted, however, that the incidence of haemolytic disease at these maternity units was six times as great as the national average.

\section{Obstructive Jaundice due to Haemolytic Disease of the Newborn}

The haemolytic process responsible for the obstructive jaundice in all these infants was due to the Rhesus factor. The results of a survey of this condition at the Maternity Hospital between April 1, 1960, and September 30, 1961, are shown in Table 2. Obstructive jaundice occurred in $10(8 \%)$ babies with $\mathrm{Rh}$ haemolytic disease. 
Haemoglobin was estimated as oxyhaemoglobin by photoelectric absorptiometer (Unicam) (Hb $100 \%=14.8 \mathrm{~g} . / 100 \mathrm{ml}$.).

On the cord blood specimens, total bilirubin was estimated by King and Coxon's method (1950), and it was only on subsequent specimens of sera that the presence of an obstructive element was demonstrated by the use of Lathe and Ruthven's (1958) modification of the diazo method. The total bilirubin of these later specimens was also checked using the spectrophotometric method of White, Haidar and Reinhold (1958).

An indirect reacting serum bilirubin of $20 \mathrm{mg}$. $100 \mathrm{ml}$. or above was considered an indication for exchange transfusion.

\section{Case Material}

The cases of obstructive jaundice due to haemolytic disease of the newborn occurring in the 18-month survey (Cases 1-10) will now be reported along with the other four cases (Cases 11-14) seen during the full two-year period. Their main clinical and biochemical features are summarized in Tables 3 and 4, and in Fig. 1.

It will be seen (Table 3) that there were no previous sibs with haemolytic disease of the newborn in eight cases, but that of the remaining six, three had had a past history of hydropic stillbirth. A moderately high or high titre of $R h: D$ antibody was present in all mothers save one that had a high titre of anti Rh:c. The ABO grouping of mother and baby is worth noting in that it bears out Levine's observation (1943) that ABO incompatibility tends to protect the mother from Rhesus sensitization. The colour of the liquor, the sex incidence and the maturity of these babies will be referred to later.

At birth all but two babies were very ill. Five presented resuscitation problems. All were noted to be

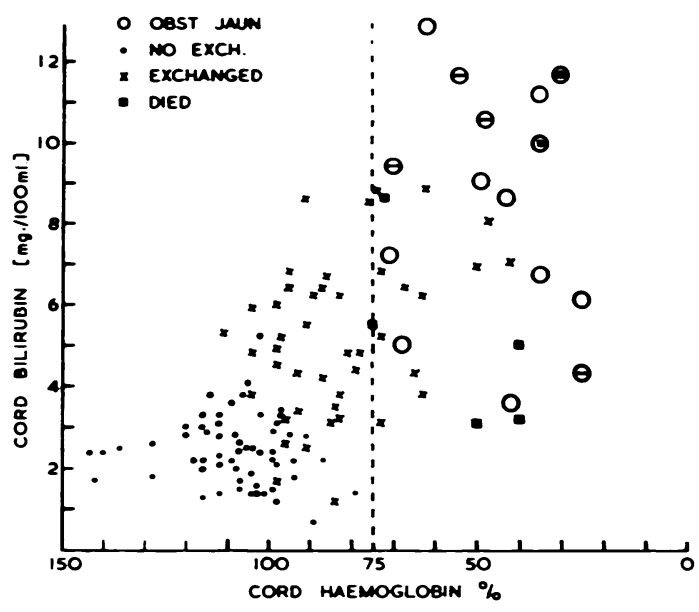

FK. 1.-Haemoglobin and total serum bilirubin values in the umbilical cord blood of 122 babies with $R$ h haemolytic disease (Table 2) showing the relation between obstructive jaundice and severe anaemia and hyperbilirubinaemia at birth and subsequent mortality. The four cases of obstructive jaundice (Cases 11-14) outside the series are included, but are shown as $\theta$.

TABLE 2

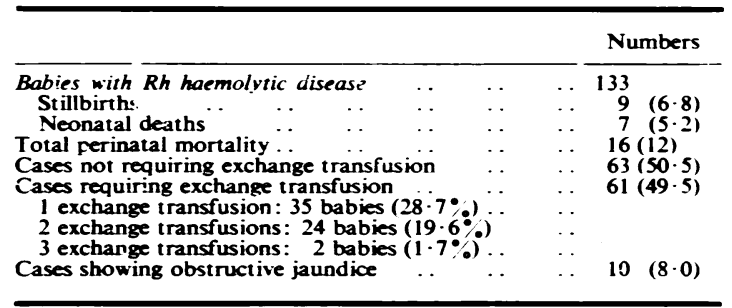

Percentages are given in parenthesis.

TABLE 3

SUMMARY OF MAIN FEATURES OF CASES WITH OBSTRUCTIVE JALNDICE

\begin{tabular}{|c|c|c|c|c|c|c|c|c|c|c|c|c|c|c|c|c|}
\hline \multirow{2}{*}{\multicolumn{3}{|c|}{ Details of Cases }} & \multicolumn{14}{|c|}{ Cases With Obstructive Jaundice } \\
\hline & & & 1 & 2 & 3 & 4 & 5 & 6 & 7 & 8 & 9 & 10 & 11 & 12 & 13 & 14 \\
\hline \multicolumn{3}{|c|}{$\begin{array}{l}\text { Birth rank } \\
\text { Previous sibs with haemolytic disease }\end{array}$} & 2 & 3 & 2 & 4 & 7 & 2 & 3 & 5 & 3 & 3 & 2 & 2 & 4 & 3 \\
\hline \multicolumn{3}{|c|}{ 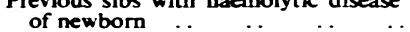 } & $\mathbf{0}$ & 0 & $\mathbf{0}$ & 2 & 1 & $\mathbf{0}$ & 1 & 2 & 1 & $\mathbf{0}$ & $\mathbf{0}$ & 0 & 0 & 1 \\
\hline \multirow{2}{*}{$\begin{array}{l}\text { Past hydropic stilibirths } \\
\text { Type maternal antibody (Rh) } \\
\text { Mother/baby ABO groups }\end{array}$} & $\ldots$ & & - & - & - & $\overline{0}$ & $\mathbf{0}$ & - & 1 & 0 & 1 & - & - & - & - & 1 \\
\hline & $\begin{array}{l}\cdots \\
\cdots\end{array}$ & & OO & $\underset{\mathbf{A B}}{\mathbf{D}} \mathbf{A}$ & $\underset{\mathbf{A}}{\mathbf{D}}$ & $\mathbf{D}$ & $\underset{\mathbf{O} / \mathbf{O}}{\mathbf{D}}$ & $\underset{\mathbf{A} / \mathbf{O}}{\mathbf{D}}$ & $\underset{\mathbf{A}}{\mathbf{D}} \mathbf{O}$ & $\underset{\mathbf{A} / \mathbf{O}}{\mathbf{D}}$ & $\mathbf{B} \mathbf{c}$ & $\underset{\mathbf{A} / \mathbf{A}}{\mathbf{D}}$ & $\underset{\mathbf{B} / \mathbf{B}}{\mathbf{D}}$ & $\underset{\mathbf{A} / \mathbf{A}}{\mathbf{D}}$ & $\mathbf{O} / \mathbf{O}$ & $\stackrel{\mathbf{D}}{\mathbf{A B} / \mathbf{A}}$ \\
\hline \multirow{2}{*}{$\begin{array}{l}\text { Colour of liquor amnii .. } \\
\text { Type of delivery } \\
\text { Gestationa! age (weeks) }\end{array}$} & $\begin{array}{l}\cdots \\
\cdots\end{array}$ & & $\stackrel{?}{\mathbf{N}}$ & $\stackrel{?}{\mathbf{N}}$ & $\stackrel{?}{\mathbf{F}}$ & G & $\mathbf{G}$ & $\dot{\mathbf{N}}$ & $\mathbf{Y}$ & $\stackrel{?}{\mathbf{N}}$ & $\mathbf{G}$ & $\mathbf{Y}$ & $\stackrel{?}{\mathrm{C}}$ & $\mathbf{G}$ & $\mathbf{G}$ & $\mathbf{Y}$ \\
\hline \multirow{2}{*}{\multicolumn{2}{|c|}{$\begin{array}{lll}\text { Gestationa: age (weeks) } & \ldots \\
\text { Sex } & \cdots & \cdots\end{array}$}} & & 38 & 39 & 38 & 38 & 39 & 38 & 35 & 35 & 38 & 39 & 40 & ? & 37 & 34 \\
\hline & & $\begin{array}{l}\cdots \\
\therefore\end{array}$ & 2.3 & $\mathbf{M}_{1.3}$ & $\begin{array}{l}M \\
1.9\end{array}$ & $\underset{\mathbf{M}}{?}$ & $\begin{array}{l}F \\
1.8\end{array}$ & F & 2.14 & $\stackrel{M}{M}$ & $\begin{array}{l}M \\
1.5\end{array}$ & $\mathrm{M}_{1.12}$ & $\begin{array}{l}F \\
1.6\end{array}$ & $\dot{\mathbf{M}}$ & $\underset{\mathbf{M}}{?}$ & $\underset{\mathbf{M}}{?}$ \\
\hline \multicolumn{2}{|l|}{$\begin{array}{ll}\text { Placental weignt (Ib. oz.) } & \ldots \\
\text { Birth weight (lb. oz.) } & \ldots\end{array}$} & $\cdots$ & 7.15 & 6.8 & 6.5 & 7.7 & 7.6 & 7.7 & 7.7 & 4.15 & 5.10 & 7.10 & 7.10 & 5.3 & 5.6 & 4.11 \\
\hline \multicolumn{2}{|l|}{$\begin{array}{c}\text { Condition at birth: } \\
\text { General }\end{array}$} & & $\mathbf{P}$ & $F$ & $\mathbf{P}$ & $\mathbf{P}$ & $F$ & $P$ & P & P & - & $\mathbf{p}$ & $\mathbf{P}$ & P & P & $\mathbf{P}$ \\
\hline Pallor.. & $\cdots$ & $\cdots$ & - & ? & $\underline{-}$ & 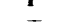 & I & + & $\underline{\mathbf{P}}$ & $\underline{P}$ & $\underline{\mathbf{F}}$ & $\underline{\mathbf{P}}$ & $\underline{\mathbf{P}}$ & P & $\underline{\mathbf{P}}$ & $\underline{P}$ \\
\hline Jaundice & . & $\cdots$ & - & - & - & - & - & - & - & - & - & - & - & - & - & - \\
\hline Oedema & .. & .. & - & - & - & - & - & ? & - & - & - & - & - & - & - & - \\
\hline Abdominal distension & & . & - & - & - & - & - & $\div$ & - & - & - & - & - & - & - & - \\
\hline Hepatosplenomegaly (grade & $(1-4)$ & . & 4 & 1 & 2 & 4 & 4 & 4 & 4 & 4 & 3 & 3 & 4 & 2 & 4 & 4 \\
\hline
\end{tabular}

$\mathbf{G}=$ Green; $\mathbf{Y}=$ Yellow $\mathbf{P}=$ Poor $; \mathbf{F}=$ Fair; $\mathbf{N}=$ Normal delivery: $\mathbf{F}=$ Forceps: $\mathbf{C}=$ Caesarian section; $\mathbf{B}=\mathbf{B}$ reech 
TABLE 4

SUMMARY OF MAIN FEATURES OF CASES WITH OBSTRUCTIVE JAUNDICE

\begin{tabular}{|c|c|c|c|c|c|c|c|c|c|c|c|c|c|c|}
\hline \multirow[t]{2}{*}{ Case } & \multicolumn{2}{|c|}{ Cord Blood } & \multicolumn{3}{|c|}{$\begin{array}{l}\text { First Differential } \\
\text { Serum Bilirubin } \\
\text { (mg./100 ml.) }\end{array}$} & \multicolumn{2}{|c|}{ No. of Transfusions } & \multicolumn{3}{|c|}{$\begin{array}{c}\text { Maximum Serum } \\
\text { Bilirubin } \\
\text { (mg } / 100 \mathrm{ml} .)\end{array}$} & \multicolumn{3}{|c|}{ Corticosteroids } & \multirow{2}{*}{$\begin{array}{c}\text { Dura- } \\
\text { tion } \\
\text { of } \\
\text { Jaun- } \\
\text { dice } \\
\text { (wks) }\end{array}$} \\
\hline & $\underset{(\%)}{H b}$ & $\begin{array}{c}\text { Serum } \\
\text { Bilirubin } \\
\text { (mg } \\
100 \mathrm{ml} .)\end{array}$ & $\begin{array}{l}\text { Age } \\
\text { (hrs) }\end{array}$ & Total & Direct & Exchange & Simple & $\begin{array}{c}\text { Age } \\
\text { (days) }\end{array}$ & Total & Direct & $\begin{array}{l}\text { Drug and Dose } \\
\text { per lb. Body } \\
\text { Weight/Day }\end{array}$ & $\begin{array}{l}\text { Age } \\
\text { When } \\
\text { Started } \\
\text { (days) }\end{array}$ & $\begin{array}{l}\text { No. } \\
\text { of } \\
\text { Days } \\
\text { Given }\end{array}$ & \\
\hline $\begin{array}{l}1 \\
2\end{array}$ & $\begin{array}{l}25 \\
62\end{array}$ & $\begin{array}{r}6 \cdot 1 \\
13 \cdot 2\end{array}$ & $\begin{array}{l}3 \\
5\end{array}$ & $\begin{array}{r}9 \cdot 0 \\
21 \cdot 0\end{array}$ & $\begin{array}{l}2 \cdot 1 \\
7 \cdot 6\end{array}$ & 2 & $\begin{array}{l}1 \\
0\end{array}$ & 2 & $\begin{array}{l}23 \cdot 3 \\
25 \cdot 4\end{array}$ & $\begin{array}{r}7 \cdot 5 \\
14 \cdot 3\end{array}$ & $\begin{array}{c}\text { None } \\
\text { Prednisolone }\end{array}$ & -4 & $\overline{5}$ & 1 \\
\hline 3 & 35 & $6 \cdot 7$ & 6 & $10 \cdot 0$ & $4 \cdot 1$ & 1 & 3 & 4 & $13 \cdot 2$ & $9 \cdot 4$ & Prednisolone & 23 & 55 & 15 \\
\hline 4 & 71 & $7 \cdot 2$ & 6 & $15 \cdot 4$ & $1 \cdot 8$ & 3 & $\mathbf{0}$ & 4 & $26 \cdot 0$ & $15 \cdot 7$ & Cortisone & 4 & 7 & 3 \\
\hline 5 & 42 & $8 \cdot 9$ & 3 & $12 \cdot 9$ & $8 \cdot 5$ & 1 & 1 & 5 & $37 \cdot 4$ & $31 \cdot 2$ & $\begin{array}{c}\text { Prednisolone } \\
1 \rightarrow 2 \mathrm{mg}\end{array}$ & 2 & 17 & 3 \\
\hline 6 & 43 & $8 \cdot 6$ & 3 & $9 \cdot 6$ & $1 \cdot 5$ & 2 & 0 & 8 & $8 \cdot 4$ & $7 \cdot 6$ & Prednisolone & 2 & 11 & 2 \\
\hline $\begin{array}{l}7 \\
8 \\
9\end{array}$ & $\begin{array}{l}35 \\
30 \\
35\end{array}$ & $\begin{array}{r}9 \cdot 9 \\
11 \cdot 6 \\
11 \cdot 1\end{array}$ & $\begin{array}{l}1 \\
3 \\
7\end{array}$ & $\begin{array}{r}6 \cdot 2 \\
11 \cdot 8 \\
16 \cdot 1\end{array}$ & $\begin{array}{l}3 \cdot 9 \\
7 \cdot 9 \\
5 \cdot 0\end{array}$ & $\begin{array}{l}1 \\
1 \\
1\end{array}$ & $\begin{array}{l}\text { Died } \\
\text { Died } \\
1\end{array}$ & $\begin{array}{l}3 \mathrm{hr} \\
8 \mathrm{hr} \\
5\end{array}$ & $\begin{array}{r}5 \cdot 5 \\
12 \cdot 6 \\
29 \cdot 8\end{array}$ & $\begin{array}{r}4 \cdot 9 \\
8 \cdot 2 \\
20 \cdot 3\end{array}$ & $\begin{array}{l}\text { None } \\
\text { None } \\
\text { Cortisone } \\
4 \mathrm{me}\end{array}$ & $\begin{array}{l}\text { Died } \\
\text { Died } \\
2\end{array}$ & $\overline{25}$ & $\frac{-}{2}$ \\
\hline $\begin{array}{l}10 \\
11\end{array}$ & $\begin{array}{l}49 \\
54\end{array}$ & $\begin{array}{r}9 \cdot 0 \\
11 \cdot 6\end{array}$ & 46 & $\begin{array}{r}8 \cdot 2 \\
19 \cdot 5\end{array}$ & $\begin{array}{l}4 \cdot 5 \\
5 \cdot 5\end{array}$ & $\begin{array}{l}1 \\
2\end{array}$ & 1 & $\begin{array}{l}2 \\
2\end{array}$ & $20 ? \cdot 5$ & $\stackrel{?}{10 \cdot 7}$ & $\begin{array}{l}\text { None } \\
\text { Cortisone } \\
1.5 \mathrm{mg} \text {. }\end{array}$ & $\overline{2}$ & $\overline{6}$ & $\frac{1-2}{1}$ \\
\hline 12 & 70 & $9 \cdot 1$ & 12 & $14 \cdot 3$ & $2 \cdot 7$ & 2 & 0 & 4 & $18 \cdot 2$ & $14 \cdot 3$ & Cortisone & 2 & 8 & 11 \\
\hline 13 & 25 & $4 \cdot 3$ & 32 & $18 \cdot 9$ & $5 \cdot 7$ & 1 & 2 & 3 & $22 \cdot 8$ & $16 \cdot 8$ & Prednisolone & 2 & 11 & 2 \\
\hline 14 & 48 & $10 \cdot 5$ & 60 & $25 \cdot 2$ & $7 \cdot 5$ & 3 & 1 & 3 & $28 \cdot 4$ & $10 \cdot 8$ & $\begin{array}{l}\text { Prednisolone } \\
1 \mathrm{mg} .\end{array}$ & 3 & 27 & 3 \\
\hline
\end{tabular}

pale and 13 jaundiced. At least six were oedematous, and hepatosplenomegaly, present in every case, was largely responsible for the abdominal distension noted in ten.

The 'cord blood' findings are shown in Table 4 and are also plotted in Fig. 1 along with those of all the other babies with $\mathrm{Rh}$ incompatibility mentioned in the survey (Table 2). Both mortality and obstructive jaundice are shown to be closely associated with the degree of anaemia at birth. No baby whose cord blood haemoglobin was over $75 \%$ either died or developed obstructive jaundice. Where the $\mathrm{Hb}$ was below $75 \%$, one-quarter died and nearly half became obstructed; and when $\mathrm{Hb}$ was below $50 \%$, about one-third died and at least three-quarters became obstructed. It will also be seen that all babies with cord blood total bilirubins over $9 \mathrm{mg} . / 100 \mathrm{ml}$. demonstrated obstructive jaundice. Of the seven deaths in the survey (Table 2), all of which took place within 24 hours of birth, two showed obstructive jaundice before they died, one did not (Fig. 3) and the other four were insufficiently investigated.

When first estimated, usually within a few hours of birth (Table 4), the direct reacting bilirubin was always above $1.5 \mathrm{mg} . / 100 \mathrm{ml}$. and often much higher. Its peak was reached in all but one of these cases before the fifth day. Clinical evidence of obstructive jaundice was seen by the passage of dark urine containing bile, pale or white stools for one to three days (five cases) and jaundice of a green hue. The latter made its appearance in 10 of the 12 survivors during the first three days of life. It was observed when there was as little as $5 \mathrm{mg}$./ $100 \mathrm{ml}$. direct bilirubin out of a total bilirubin of $20 \mathrm{mg} . / 100 \mathrm{ml}$.
Complications were very common. Signs of heart failure occurred in at least six cases, the respiratory distress syndrome in eight, meconium-inhalation 'pneumonitis' in two, a paralytic ileus causing temporary intestinal obstruction in two, and cyanotic attacks in nine. A tendency to bleed was seen in seven cases (skin, five; haematemesis, two; lungs, one; injection sites, one; brain, three) and was sometimes present at birth. Finally, signs of cerebral disturbance were noted in six babies and were thought to be due to kernikterus in at least two (Cases 4 and 14). One of these babies now exhibits selective deafness at 1 year. No other cases of kernikterus were seen in the neonatal period during these two years.

In the management of these cases, vitamin $K(0 \cdot 5-1 \cdot 0$ mg. intramuscularly) was ordered routinely, and digitalization, normally reserved by us for the most severely affected, was thought necessary in all these infants. Exchange transfusion was required in every case and two-and-a-half times as frequently in this group as in all babies with $R \mathbf{h}$ haemolytic disease. Late transfusion for anaemia was required over five times as often as for the whole group. Corticosteroids were given to 10 of the 12 survivors.

Jaundice never lasted more than three and a half weeks (Table 4), except in Case 3 (15 weeks). It is worth recording that in this case corticoid was not given till the age of 3 weeks. Liver function tests on this baby were grossly abnormal at 1 week (S.G.O.T. 132 units; S.G.P.T. 61 units; alkaline phosphatase, 18 K.-A. units), and also at 1 month (S.G.O.T. 132 units; S.G.P.T. 63 units; alkaline phosphatase 23 K.-A. units). In the only other infant (Case 9) where liver function tests 


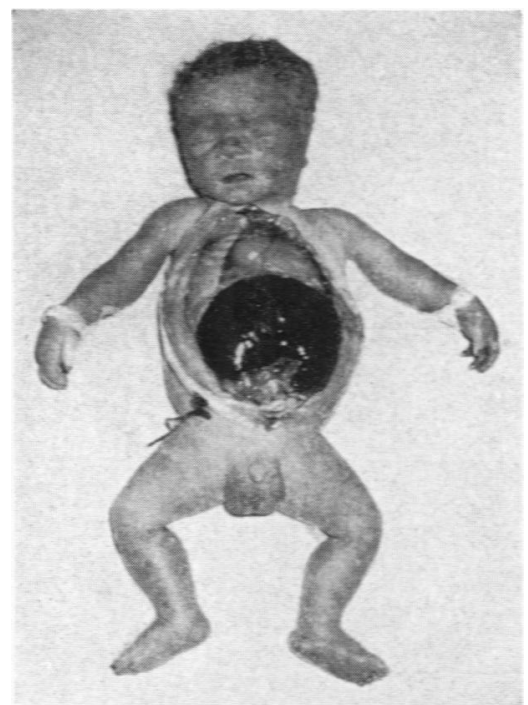

FG. 2.-Case 7 : hydrops foetalis at autopsy. Note the gross hepatosplenomegaly and the ecchymoses mainly on the face.

were performed (at 3 months), they were again abnormal (S.G.P.T. 87 units; alkaline phosphatase 38 K.-A. units), and hepatosplenomegaly was still present in this baby at the age of 6 months. No long-term follow-up is yet possible.

Two case histories follow.

Case 3. This baby was the first of twins; both were affected by $\mathrm{Rh}$ haemolytic disease, but only one showed obstructive jaundice. The mother, aged 31 , had had one normal infant. She was $O R h$ negative and had a high titre of $R h(D)$ antibodies. At 38 weeks' gestation twins were born by the aid of forceps. Their features are compared together in Table 5.

TABLE 5

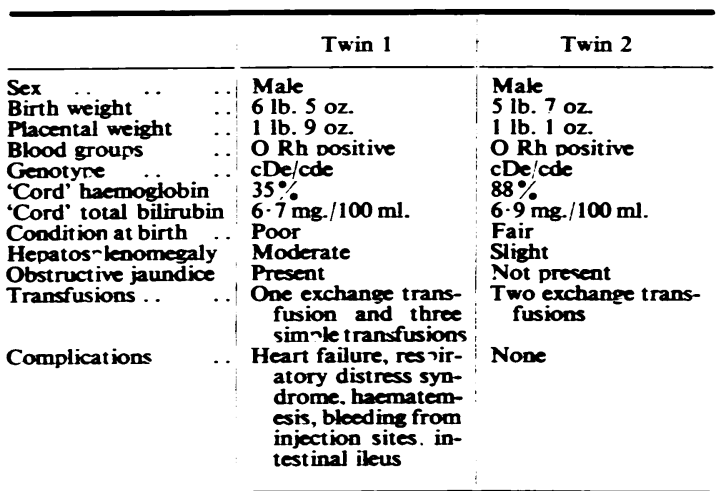

Case 7. The second case history is included because the baby died and post-mortem material is shown in Figs. 2 and 4 . The mother, aged 36, had had two babies previously. The first was normal and the second a hydropic stillbirth. She was $A$ Rh negative, with a high titre of anti-Rh(D). In the present pregnancy, she was delivered at 35 weeks' gestation by caesarian section of a boy weighing $7 \mathrm{lb}$. $7 \mathrm{oz}$. and a placenta weighing $2 \mathrm{lb}$. $14 \mathrm{oz}$. Both were hydropic. At birth the baby demonstrated asphyxia pallida, congestive cardiac failure, gross hepatosplenomegaly and many ecchymoses especially on the face. In spite of digitalization and a small exchange transfusion undertaken at $1 \frac{1}{2}$ hours, he died aged 4 hours.

Autopsy. The findings were typical of hydrops foetalis due to erythroblastosis (Fig. 2). Effusions were present in all body cavities.

Histology. The lungs showed hyaline membrane disease. In the liver (Fig. 4) there was considerable proliferation of the bile-ducts in the portal tracts. The lobules consisted largely of syncytial masses of pigmented multinucleated liver cells. The small cytoplasmic granules were mainly of haemosiderin and the larger bodies were due to bile pigments. Bile thrombi were present in some of the canaliculi and there was also excessive extramedullary erythropoiesis.

\section{Discussion}

The incidence of obstructive jaundice in haemolytic disease of the newborn is probably between 8 and $10 \%$ (Table 6).

Haemolytic disease of the newborn is the most common cause of obstructive jaundice in the newborn, though this may not be so apparent from those babies admitted to a children's hospital. While all our cases were due to $\mathrm{Rh}$ incompatibility, obstructive jaundice may follow exceptionally severe cases of incompatibility due to ABO (Harris et al., 1954), Kell (Ivemark, Högman, Rudert and Andersen, 1959) or other groups.

The occurrence of 11 males to three females in this series may be of no significance. However, the preponderance of males among fatal cases and cases of kernikterus due to haemolytic disease is well known (Walker and Mollison, 1957) and male sex hormone therapy may cause cholestasis in adults (Schaffner, 1960). Also Allen, Diamond and Watrous (1949) showed that the use of male, rather

TABLE 6

\begin{tabular}{|c|c|c|c|}
\hline \multirow[b]{2}{*}{ Reported Series } & \multicolumn{3}{|c|}{ Hacmolytic Disease of Newborn } \\
\hline & $\begin{array}{c}\text { Total } \\
\text { No. }\end{array}$ & $\begin{array}{l}\text { No. with } \\
\text { Obstructive } \\
\text { Jaundice }\end{array}$ & $\begin{array}{l}\text { \% with } \\
\text { Obstructive } \\
\text { Jaundice }\end{array}$ \\
\hline $\begin{array}{l}\text { Stempfel et al. (1956) } \\
\text { Oppé and Valaes (1959) } \\
\text { Present Series }\end{array}$ & $\begin{array}{r}83 \\
117 \\
124\end{array}$ & $\begin{array}{r}7 \\
12 \\
10\end{array}$ & $\begin{array}{r}8 \cdot 4 \\
10 \cdot 2 \\
8 \cdot 0\end{array}$ \\
\hline
\end{tabular}




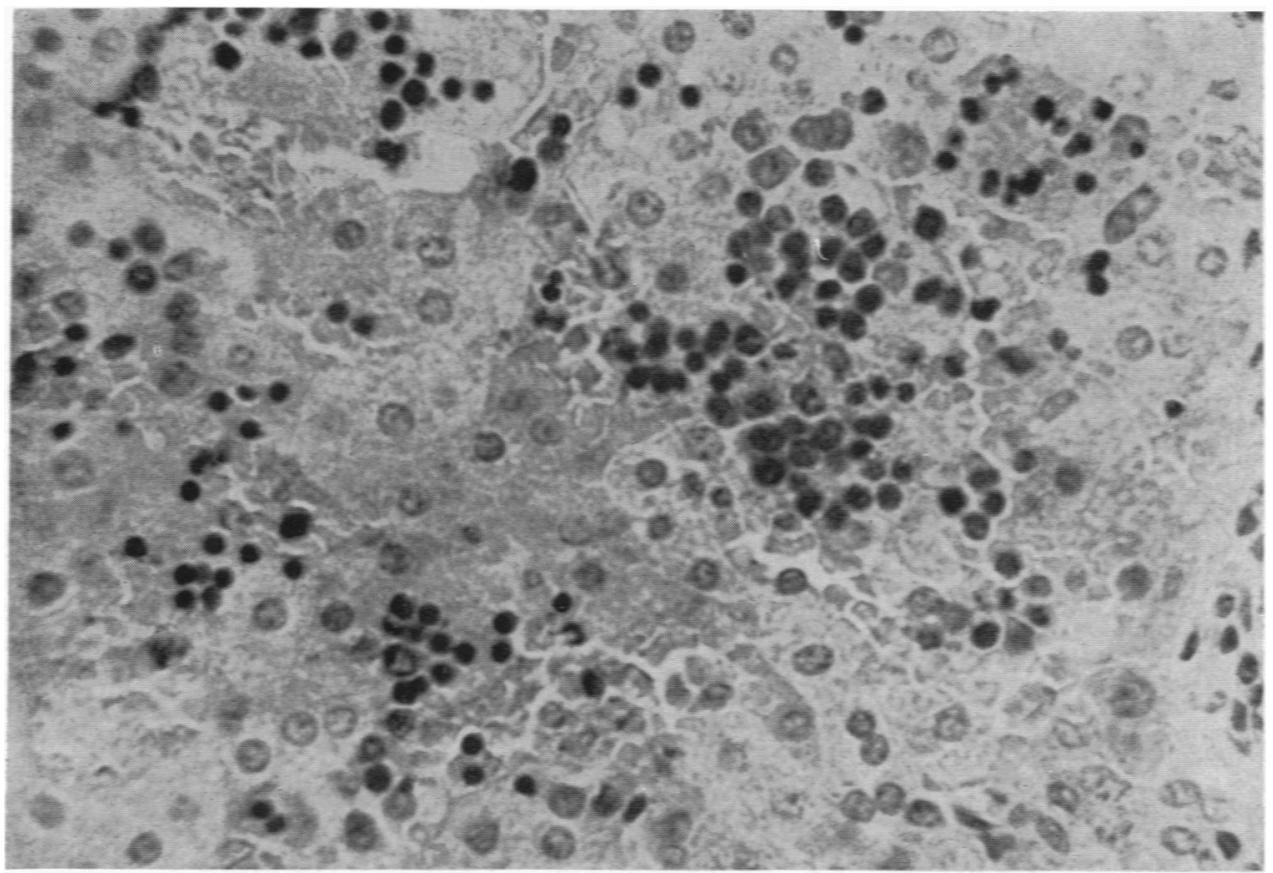

Fig. 3.-Post-mortem section of the liver of a baby of 35 weeks' gestation with Rh haemolytic disease (cord blood Hb $75 \%$ ), but without obstructive jaundice, who died age 8 hours. Shows normal bobular architecture with abundant extramedullary erythropoietic tissue. (H. and E. $\times 364$.)

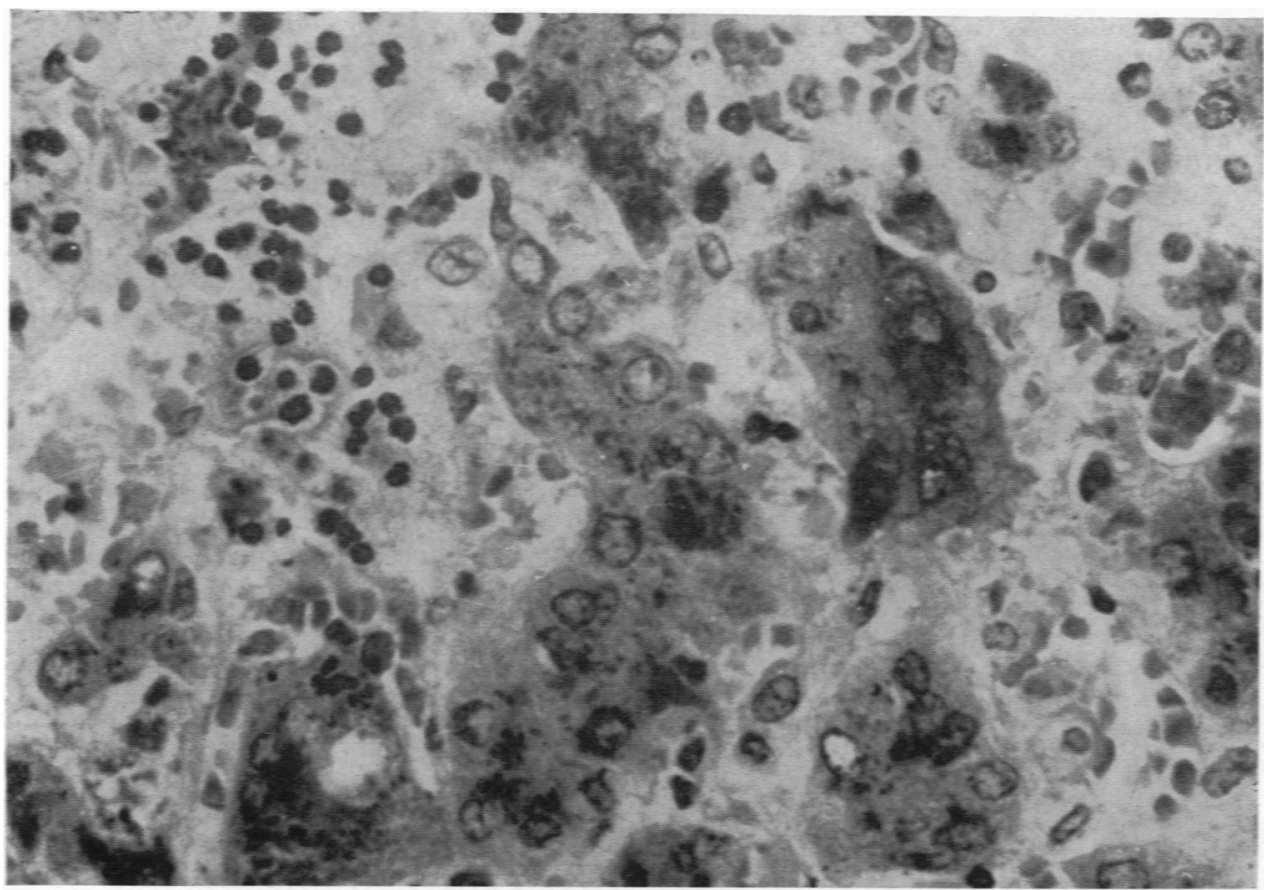

Fig. 4.- Case 7: post-mortem section of the liver of a baby of 35 weeks'sestation with severe Rh haemolytic disease (cord blood $\mathrm{Hb} 35 \%$ ) and obstructive jaundice, who died age 4 hours. Shows disorganization of hepatic architecture, many multinucleated giant cells containing granules of bik pigment and haemosiderin, excessive erythropoiesis and bile thrombi. (H. and E. $\times 364$.) 
than female, donor blood for exchange transfusion was accompanied by a much greater mortality. At that time, only one exchange transfusion was thought necessary and the increased mortality was presumably due to kernikterus.

Oppé and Valaes (1959) suggested that babies of less than 36 weeks' gestation could not develop obstructive jaundice because of inability to conjugate bilirubin. Yet, in this series, three were under 36 weeks' gestation (Table 3), and two of these later died. The high mortality among immature babies with obstructive jaundice probably accounts for it being rarely diagnosed in the premature infant.

The obstructive jaundice of haemolytic disease may often be detected at birth, a cord blood 'direct' bilirubin over $1 \mathrm{mg} . / 100 \mathrm{ml}$. being highly suspicious and over $2 \mathrm{mg}$./100 ml. pathognomonic of this condition. Thereafter, the biochemical diagnosis depends on a rise of the 'direct' bilirubin above $3 \mathrm{mg}$. $100 \mathrm{ml}$. Clinically, all severely affected cases of haemolytic disease of the newborn should be suspect. Jaundice of a green hue is often of diagnostic value. As bilirubin diglucuronide is yellow, this green coloration may be caused by its conversion to another pigment, possibly biliverdin.

Green liquor amnii was reported in some of these cases and was difficult to distinguish from meconium staining. This on occasion led to a faulty diagnosis of foetal distress. In this condition, where cholestasis is often present before birth, urobilin and related pigments would be expected in the foetal urine and hence lend colour to the liquor.

Kove, Goldstein, Perry and Wróblewski (1959) have used the serum transaminase levels in the differential diagnosis of neonatal jaundice. While these were within normal limits in mild or moderately severe haemolytic disease, the levels were raised, indicating hepatocellular damage, in very severe cases and when there was obstructive jaundice. The serum transaminase findings in our two cases confirm this.

The importance of recognizing this condition lies in its complications and their prevention, its high mortality, the need to institute specific treatment, the possibility of avoiding unnecessary exchange transfusions and finally the need to distinguish it from other causes of cholestasis. Should the jaundice persist, this distinction may become very difficult later in infancy. Complications of the exchange transfusion such as serum hepatitis or portal vein thrombosis (Shaldon and Sherlock, 1962; Tizard, 1962) may further confuse the issue. A less severe form of obstructive jaundice that appears later may follow relatively mild cases of haemolytic disease of the newborn (Jouvenceaux, Brizard,
Michaud and Revol, 1959; Zuelzer and Brown, 1961a). No cases of this type were seen in the present series and this may be due to early and adequate transfusion therapy.

Haemorrhagic disease appears to be a frequent complication of this condition and may be present at birth. It is probably an expression of liver damage. Besides hypoprothrombinaemia, there may be a deficiency of convertin and other coagulation factors (van Creveld, 1959). Vitamin K, or preferably $K_{1}$ (Jouvenceaux et al., 1959), should be given by intramuscular injection at birth and repeated if necessary. Fresh blood or transfusion with triple strength plasma may be required. It is possible that citrated blood is safer than heparinized for transfusion in these cases.

When contemplating exchange transfusion for hyperbilirubinaemia in these infants, the directreacting fraction of the serum bilirubin was discounted as a factor in the causation of kernikterus. In the two cases of kernikterus reported above, occurring after three and two exchange transfusions within 48 hours of birth, the 'indirect' serum bilirubins, when symptoms first appeared, were initially reported to be below $20 \mathrm{mg}$. $/ 100 \mathrm{ml}$. However, re-estimation showed them to be well above this level. While there is a natural reluctance to transfuse such seriously ill babies unnecessarily. it does appear that they are at especial risk from kernikterus. This may be due to the associated pathology or to coexistent complications causing hypoxia (Zuelzer and Brown, 1961b). Finally, the very high levels of serum bilirubin that frequently occur may lead to errors in estimation.

The early use of corticoid in this condition was thought to be of benefit, though this opinion was only based on clinical impression. Many reports are available on the use of these drugs in both obstructive jaundice and hepatitis (Summerskill, Clowdus, Bollman and Fleisher, 1961; Williams and Billing, 1961), in cirrhosis (Effersoe and Kjerulf, 1962), and in hyperbilirubinaemia of prematurity (Crosse and Corney, 1961 ; E. E. Hill, 1961, personal communication). The general consensus of opinion suggests that corticosteroids both reduce jaundice and improve liver function and are of especial use when there is liver cell damage. The continued empirical use of this drug when cholestasis is present seems justified.

The microscopical appearance of the liver in this condition has been fully recorded (Hawksley and Lightwood, 1934; Craig, 1950; Cameron and Hou, 1962). The findings in the two babies that died (Case 7 is reported above) appeared to be typical. In addition to necrosis, giant-cell regeneration and 
other evidence of hepatic damage, fibrosis may be present at birth (Henderson, 1942: Cornblath et al., 1955) or appear in the succeeding weeks (Hawksley and Lightwood, 1934). The microscopical appearance of the liver of Case 7 (Fig. 4) is contrasted with that of another baby of 35 weeks' gestation, who had $\mathrm{Rh}$ haemolytic disease but no obstructive jaundice (Fig. 3). The latter shows a normal lobular architecture in spite of the presence of excessive extramedullary erythropoietic tissue. No bile pigment or thrombi are present. This baby died from the respiratory distress syndrome.

In haemolytic disease of the newborn the liver, which is the seat of excessive erythropoiesis, receives blood rich in maternal antibodies straight from the placenta. Whether the resulting intense haemolytic reaction damages the liver or whether the damage is caused by anoxia following anaemia or congestive cardiac failure, is not known. Certainly gross functional and often anatomical liver cell damage is present in these cases. The structural abnormality common to all forms of cholestasis, seen only under the electron microscope, is an alteration of the bile canaliculi (Schaffner, 1960). Necrosis of the liver cells involves rupture and destruction of the associated canaliculi which are merely modifications of the walls of the liver cells (Cameron and Hou, 1962). It is suggested that once cellular breakdown has occurred, protein may enter the canaliculi and produce a precipitation of the bile components (MacClure, 1931; Eppinger, 1937). The resulting bile thrombi may secondarily block the bile passages. It is worth recalling that as long ago as 1933 Parsons, Hawksley and Gittins appreciated that hepatic damage and obstructive jaundice might occur in infants with severe erythroblastosis foetalis.

While in most cases the prognosis appears to be good (Hsia et al., 1952), as long as obstructive jaundice persists it remains in doubt (Lightwood and Bodian, 1946). Some of the most severe cases which, because of improved techniques, are now surviving may well progress to cirrhosis, hepatic failure and portal hypertension.

\section{Summary}

Eighteen cases of obstructive jaundice diagnosed in the neonatal period amongst 6,854 babies born at two maternity units during 1960-61 are reviewed. Of these cases, 14 were associated with $\mathrm{Rh}$ haemolytic disease. The incidence of obstructive jaundice in the latter appears to be $8-10 \%$. Their common clinical and biochemical features are analysed and discussed. The diagnosis is also discussed and the importance of early detection by differential serum bilirubin studies is emphasized.
The severity of the haemolytic disease in these babies, associated with a high mortality and complications such as kernikterus and haemorrhagic diatheses, is stressed. Evidence is produced to indicate that the obstructive jaundice in these cases is due primarily to liver cell damage.

Treatment with corticosteroids appears to be beneficial.

I am greatly indebted to Dr. B. S. B. Wood for his help and direction; also for both his and Dr. B. D. Bower's permission to report their cases, and to the obstetricians who supervised their antenatal care; to Dr. R. Gaddie and Dr. W. Weiner and their departments for their assistance with the biochemical investigations. and to Dr. H. G. Kohler and Dr. A. H. Cameron for their advice on the post-mortem material; finally, to Miss V. Macdonald for her secretarial assistance.

The author was in receipt of a grant from the United Birmingham Hospitals endowment fund.

\section{REFERENCES}

Allen. F. H.. Jr.. Diamond. L. K and Witrous J B Jr. (1949). Ervthroblastosis fetalis. V. The value of blood from female donors for exchange transfusion. New Engl. J. Med.. 241, 799.

Billing. B. H. and Lathe. G. H. (1958). Bilirubin metabolism in jaundice. Amer. J. Med. 24. 111

Cameron. G. R. and Hou. P. C. (1962). Biliary Cirrhosis. Oliver and Boyd. Edinburgh and London.

Cornblath. M.. Kramer. I. and Kelly. A. B. (1955). Rt isoimmunization associated with regurgitation jaundice beginning in utero: a report of two patients. Amer. J. Dis. Child. 90.628.

Craig. J. M. (1950). Sequences in the development of cirrhosis of the liver in cases of erythroblastosis fetalis. Arch. Path 49,665.

van Creveld. S. (1959). Coagulation disorders in the newborn period. J. Pediat.. 54. 633.

Crosse. V. M. and Corney. G. (1961). The use of adrenocorticotrophic hormone in neonatal jaundice in premature babies. Proc. roy. Soc. Med.. 54. 737.

Effersee. P. and Kjerulf. K. (1962). Cirrhosis of 'iver; effect of prednisolone on frequency of biochemical rclapse. Lancet, 1. 190 .

Eppinger. H. (1937). Die Leberkrankheiten. Soringer, Wien.

Harris, R. C.. Andersen. D. H. and Day. R. L. (1954). Obstructive jaundice in infants with normal biliary tree. Pediatrics. 13, 293.

Hawksley. J. C. and Lightwood. R. (1934). A contribution to the study of ervthroblastosis: icterus gravis neonatorum. Quart. J. Med. 27, 155.

Henderson. J. L. (1942). A fourth type of erythroblastosis foetalis showing hejatic cirrhosis in the macerated foetus. A report of three cases. Arch. Dis. Childh., 17. 49.

Hsia, D. Y. Y., Patterson. P.. Allen. F. H.. Diamond. L. K and Gellis. S. S. (1952). Prolonged obstructive jaundice in infancy. I. General survey of 156 cases. Pediatrics, 10. 243.

Ivemark. B. I., Högman. C.. Rudert. P. O. and Andersen, B. (1959). Kell-iso-immunization as the cause of fatal erythrohlastosic fetalis. Acta path. microbiol. scand., 45, 193.

Jouvenceaux, A.. Brizard, C. P.. Michaud, D. and Revol, L. (1959). Treatment of haemolytic disease of the newborn due to $R \mathbf{h}$ immunization. Brit med.J.. 2. 336.

King. E. J. and Coxon. R. V. (1950). Determination of bilirubin with precisitation of the plasma proteins. J. clin. Path., 3. 248.

Kove. S.. Goldstein, S., Perry. R. E. and Wróblewski, F. (1959). Diagnosis of neonatal jaundice by serum transaminase. Arch. Surg., 78, 157.

Lathe. G. H. (1955). Exchange transfusion as a means of removing bilirubin in haemolytic disease of the newborn. Brit. med. J., 1. 192.

and Ruthven. C. R. J. (1958). Factors affecting the rate of coubling of bilirubin and conjugated bilirubin in the van den coubling of bilirubin and conjugated bilir

Levine. P. (1943). Serological factors as nossible causes in spontaneous abortions. J. Hered. 34. 71 .

Lightwood, R. and Bodian, M. (1946). Biliary obstruction associated with icterus gravis neonatorum. Arch. Dis. Childh. 21, 209.

MacClure, E. (1931). Ober icterus neonatorum gravis. Z. Kinderheilk., $51,86$.

Nakai, H. and Landing. B. H. (1961). Factors in the genesis of bile stasis in infancy. Paediatrics, 27, 300. 
Oppé. T. E. and Valaes. T. (1959). Obstructive jaundice and haemolytic disease of the newborn. Lancet. 1. 536

Parsons L G Hawkley. J C and Gitins $\mathbf{R}$ (1933). Studies in the anaemias of infancy and early childhood. IV. The haemothe anaemias of infancy and early childhood. IV. The haemoIvtic (erythronoclastic) anaemias of the neonatal period; with soerial reference
Childh. 8, 159.

Schaffner, $\vec{F}$. (1960). Iatrogenic jaundice. J. Amer. med. Ass. 174,1690

Shaldon. S. and Sherlock. S. (1962). Obstruction to the extraheoatic portal system in childhood. Lancet. 1, 63.

Stempfel. R. Broman. B. Escardó. F. E. and Zetterströ.n. R. ! 1956) Obstructive jaundice comolicating hemolytic disease of the newborn. Pediatrics, 17, 471.

Still. G. F. (1927). Common Disorders and Diseases of Childhood. 5th ed., p. 375. Oxford University Press. London.

Summerskili, w. H. J., Clowdus. B. F.. Bollman, J. L. and Fkisher. G. A. (1961). Clinical and experimental studies on the effect of corticotrophin and steroid drugs on bilirubinemia. $1 m e r$. J. med. Sci.. 241. 555 .
Tisdale. W. A.. Klatskin. G. and Kinsella. E. D. (1959). The sienificance of the direct-reacting fraction of serum bilirubin in hemolyt ic jaundice. Amer. J. Med.. 26. 214.

Tizard. J. P. M. (1962). Portal hypertension following exchange transfusion through the umbilical vein. Proc. rov. Soc. Med.. 55. 772 .

Walker. W. and Mollison. P. L. (1957). Hacmolytic disease of the newborn. Deaths in England and Wales during 1953 and 1955 Laniet. 1. 1309.

White. D.. Haidar. G. A. and Reinhold. J. G. (1958). Spectrophotometric measurement of bilirubin concentrations in the serum of the newborn by the use of a microcapillary method. Clin. Chem.. 4, 211 .

Williams. R. and Billing B. H. (1961). Action of steroid therapy in jaundice. Lancet. 2. 392.

Zuelzer, $W^{\prime}$. W. and Brown. A. K. (1961a). Neonatal jaundice. Amer. J. Dis. Child. 101. 87

(1961b). Studies in hynerbilirubinemia. III. Separate metabolic defects in premature infants reflected in the partition of serum bihirubin. ibid.. 102. 815 . 